\title{
Virtual Reality Game Education to Learn Traffic Regulation
}

\author{
Andru Deva Lukito ${ }^{1}$, Ridwan Sanjaya ${ }^{2}$, Hendra Prasetya ${ }^{3}$ \\ Information Systems Department, Faculty of Computer Science \\ Soegijapranata Catholic University, Semarang, Indonesia \\ andrudeva@gmail.com¹, ridwan@unika.ac.id ${ }^{2}$, hendra@unika.ac.id ${ }^{3}$
}

Abstract - Traffic accident has become number 3 of children fatality in the world according to WHO[1]. Traffic accidents that include children are often caused by themselves for breaking the law or regulation. Education about traffic regulation and law including traffic signs and the description must be early given to children.Education is the process to change a person or a group attitude and behavior in order to make them matured through teaching and training [2]. Education that can be used is interactive digital media. It is digital game, various forms of digital game from 2D, 2.5D to 3D with many points of view and new technology. VR (Virtual Reality) as new digital media where alternate reality existschecks various theories without any real consequences.According to Greenbaum, "Virtual Reality is an alternate world filled with computer-generated images that respond to human movements. These simulated environments are usually visited with the aid of an expensive data suit which features stereophonic video goggles and fiber-optic data gloves"[3]. Greenbaum's statement before was to make VR suitable to test traffic law and regulation and educate kid to obey the traffic sign and regulation without real consequences from real world. This Journal contains the result of using virtual reality as traffic regulation education media. Education materials consist of traffic signs that appear on the road and safety riding gear.

Keywords - Virtual Reality, Traffic sign, Road traffic, children, education

\section{INTRODUCTION}

Vehicle population in Indonesia especially private vehicle according to OICA (Organisation Internationale des Constructeurs d'Automobiles) statistic shows the significant annual growth [4]. For example,the number of motorcycle in Indonesia is increasing considerably by 7,184,925 from 2014 until 2015[5], the growth of vehicle triggering another effect. The increasing road density influences the increasing risk of accident. According to WHO, traffic accidents are on the third place on children at age $0-14[1]$, and this problem becomes main concern.

Indonesia Act 2009 Number 22 about road traffic and transportation states "every person who drives a vehicle must obey: traffic sign, road marking, traffic lamp and sirens, traffic motion stop and parking, horn and light, maximum and minimum speed, coupling procedure"[6].Anyway, the number of traffic law violations keeps increasing year by year in Indonesia. In 2015, traffic law violation increased up to 34 percent or 69,786 violation[7]. Besides,adult traffic violation isexecuted by children too. This behavior leads to secondary effect like robbery, street racing, and other street crime[8]. This problem leads to aggressive driving behavior where children become impatient and dangerous for people around them[9]. Also traffic sign and traffic jam make driver become aggressive and increase chance of traffic accident[9].

High traffic accident which involves children becomesthe focus ofthe researcher to develop an education media to prevent traffic 
accident increasing by educating children with traffic sign and safety riding gear. The media used as education media was virtual reality game, to give education with virtual experience, in virtual world and generated reality[10]. Game have positive effect on both psychology and physically especially for teens in their puberty that often cause emotion instability and make teen tend to trouble[9].

This journal studies simple yet attractive traffic road regulation for elementary students from age 7 until age 11, by designing and setting specification for virtual reality gadget, and to know the result of this research.

\section{THEORETICAL FOUNDATION 2.1 Road Traffic}

Road Traffic are motion of vehicle and people in road traffic space[6]. Road Traffic is one of entity on the system with transportation vehicle[6]. Road traffic network is series of connected node or work space for transportation vehicle[6].Inorganizing road traffic, road traffic infrastructures like road and road amenities are needed for vehicle, people and goods to move[6].

Indonesia Act 2009 Number 22 about road traffic and transportation states that road traffic and transportation vehicle are one with the system consisting road traffic, transportation, road traffic network, and road traffic amenities, vehicle, driver, and the management of road traffic itself [6].Traffic sign has become one of important road amenities that are installed on every road assaid in Indonesia Act 2009 Number 22 about road traffic and transportation mentioning that traffic sign is part of road amenities including sign, letter, sentence or the combination serving as warning, instruction, and guide for driver.[6].

Drivers have responsibility to obey traffic sign as Indonesia Act 2009 Number 22 about road traffic and transportation stated on paragraph 106 Verse 47. The children traffic signs arranged based on book consist ofwarning, instruction, and guide traffic sign.

\subsection{Education}

According to Indonesian dictionary, education is a process or groupto change person manner and behavior in order to make a person or a group mature through teaching and training[11]. John Dewey said that learning was social process not preparation but life itself [12].Furthermore, John Dewey statedthat education was experience process considering as a matter of fact that life keeps changing so human will always grow and learn without age boundaries. Education is a process of learning in every phase of life and improving human skills[13].

\subsection{Video Game}

Gameis divided in several genres like action, adventure, education, racing, RolePlaying Game, simulation, sport, and strategy[14]. According to player view, games are divided on several category like First Person, Third Person, Isometric, Platform, Side Scrolling, and Top Down[14].

Game has become a method to express their feeling for generation nowadays both social and anthropology[15]. Game is not an entertainment anymore, Game has emerge as new field[15]. Many universities and teacher start to study about game as media [15]. Gamehas various effect, so game is valuable especially for teens [15].

\subsection{Virtual Reality}

Virtual Reality is a technology developed in the late 20th century. This technology aims to provide artificial experiences, the Virtual World, the Artificial World and the artificial reality [10]. Development of Virtual reality itself was originally intended for the field of health[16]. At present the Virtual Reality has been developed for flight simulations, multistore buildings, social environments, etc.[16]. Today's Virtual Reality continues to be 
developed, especially in the gaming world,a variety of games that offer First Person View experience using Virtual Reality devices. Experience with the first person perspective makes Virtual Reality a favorite with technological developments [16].

\section{METHODS}

This research aimedto know the effect of educational virtual reality game titled "Simulasi Tertib Berlalu lintas" (Simulation of Traffic Compliance). This research using closed and open question by questionnaire directly to 30 random elementary students from grade 3 until grade 6 . The sampling process was separated in two stages. First stage is Pre-Test. This stage is to test respondent's knowledge about traffic sign and safety gear when riding motorcycle. Second stage is PostTest.This stage is conducted after respondent finishes playing the game, on this stage respondentare asked to tell their knowledge about traffic sign and safety gear when riding motorcycle.

Questionnaire for both Pre-Test and Post-Test contained the same format but different question on open section. 15 closed questions contain traffic sign. In Pre-Test questionnaire, 2 questions are about safety riding gear, and 3 questions are about virtual reality experience before respondents play the game. Post-Test consists of same questions format with some difference at open questions. 2 open questions in Post-test are about safety gear riding they saw when playing game, then 3 questions are about respondents experience when playing the game.

\section{SURVEY RESULTS}

After respondent worked out pre-test and post- test, the result was:

1. 97 percent (29 out of 30 children) never played games using Virtual Reality technology.
Total respondents that already play Virtual Reality before

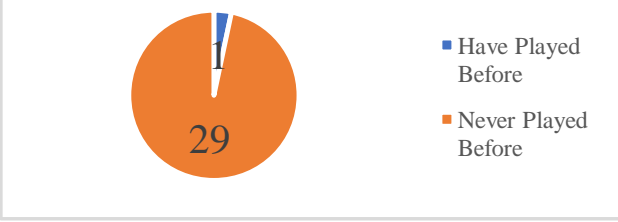

Fig. 3.1 Total of respondents already played before

2. Comparison of the total percentage of correct answers between Pre-test and Posttest by 15 percent (68 answers from 450 answers) from 80 percent -65 percent

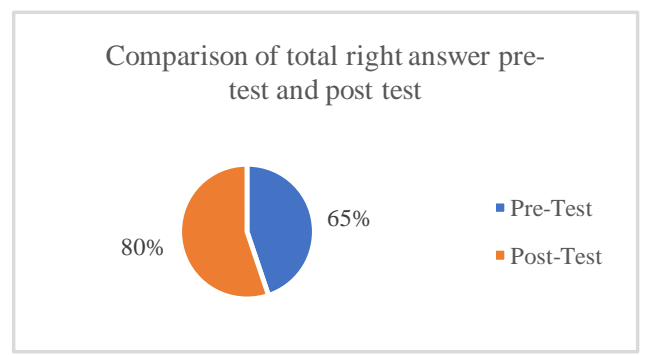

Fig. 3.2 Comparison of total right answer pre-test and post test

3. Increased knowledge can also be seen from the percentage increase in the group of respondents with the percentage of correct answers 76 percent-100 percent as much as 13 percent (4 respondents).

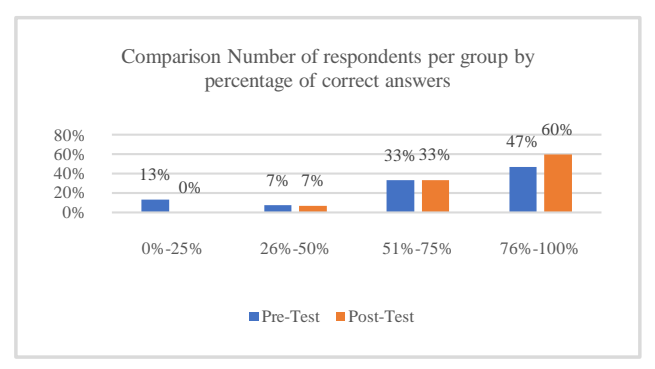

Fig. 3.3Comparison Number of respondents per group by percentage of correct answers

4. At level 3 where the respondent is asked to ride the incomplete rider either his motorcycle accessories or his rider, it teaches the respondent to always use safety equipment and check the completeness of 
the motor so that no accident can cause serious injury, here is the exposure of choice parts of motorist and motorcycle accessory Chosen by the respondent after playing. Respondents chose more rearview mirrors than ever before by 42 percent followed by 28 percent headlamps as well as turning light, speedometer and rearview mirror followed by 10 percent

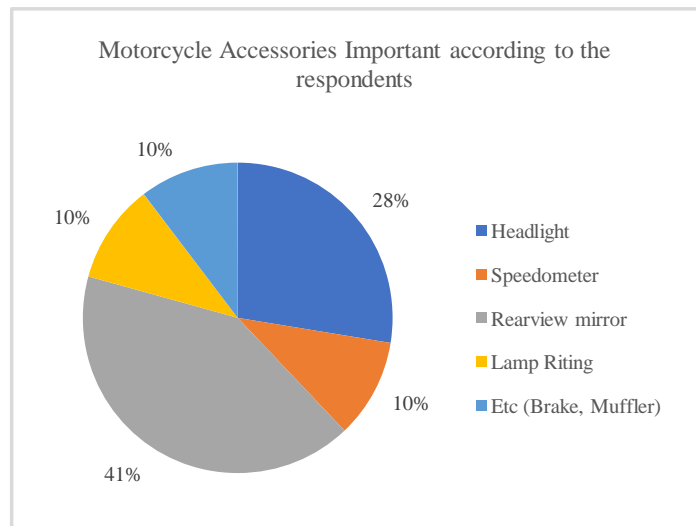

Fig. 3.4Percentage of Motorcycle Accessories Important according to the respondents

5. On the question of motorist's accessories the respondent's answer began to be divided into 60 percent helmets, jacket 19 percent, shoes 8 percent, gloves and elbow protector 5 percent, and 3 percent.

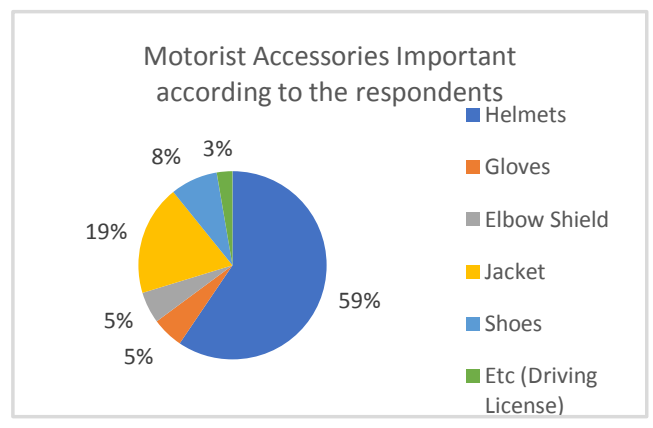

Fig. 3.5Difficulty of features utilization inside framework

6. The test results showed that 90 percent of respondents loved to play Virtual Reality games. In accordance with the formulation of problem number two, the level of pleasure of children aged 7 to 11 years is very high on the material provided with the design and specifications that are suitable and comfortable for them.

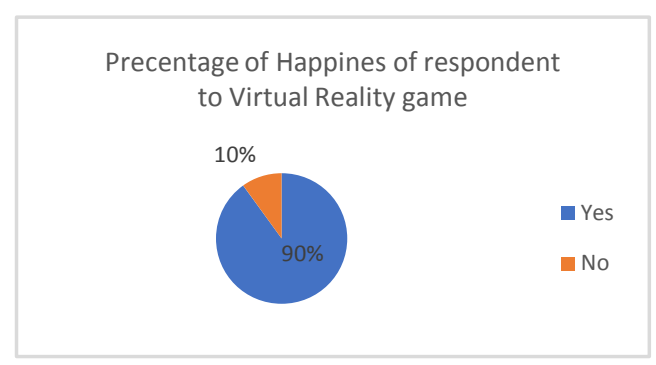

Fig. 3.6Happinesspercentage of respondent to Virtual Reality game

7. This study showed that Virtual Realitybased games could provide education in a fun way, the picture below states 73 percent of respondents feel very happy after playing the game Virtual Reality.

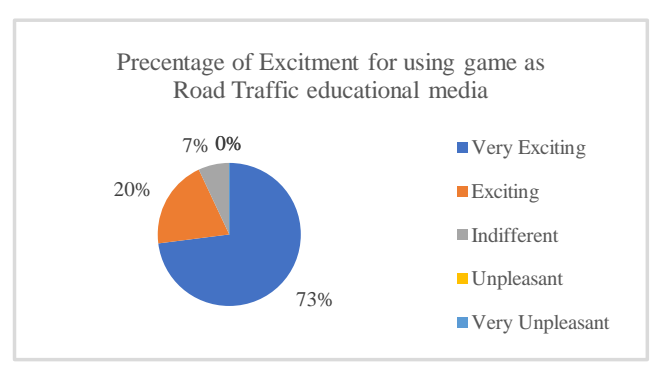

Fig. 3.7Percentage of Excitement for using game as Road Traffic educational media

\section{CONCLUSION}

Based on increasing percentage of correct answers from the pre-test at 65 percent to 80 percent with the percentage increase of 15 percent and the displacements of respondents who can only answer 0 percent 25 percent by 13 percent (4 respondents) to 0 percent as described, the education materials are compatible for children age 7-11.

This result was strengthenedby the answer from both subjects mostly show same respond in easy to use, features provided, and the installation of framework itself.

From the gathered data, many respondents desired to play the game again. 
The material were not too hard for them so virtual reality needed to be more developed for educational purpose and made it reliable, sturdy, and easy to use for teacher globally.

\section{REFERENCES}

[1] WHO, "Global Burden Disease Death Estimates Sex Age 2000-2015,” www.who.int, 2015.

[Online]. Available:

http:/www.who.int/entity/healthinfo/global_bur den_disease/GHE2015_Deaths_Global_2000_2 015.xls?ua $=1$.

[2] Pusat Bahasa(Kementrian Pendidikan dan Budaya), “Arti Pendidikan menurut KBBI.” [Online]. Available: http://kbbi.web.id/didik.

[3] J. Steuer, "Defining Virtual Reality: Dimensions Determining Telepresence,” J. Commun., vol. 42, no. 4, pp. 73-93, 1992.

[4] OICA (Organisation Internationale des Constructeurs d'Automobiles), "Global Total Vehicles in use,” www.oica.net, 2015. [Online]. Available: http://www.oica.net/wpcontent/uploads//PC_Vehicles-in-use.xlsx.

[5] BPS Indonesia (Badan Pusat Statistik), "Statistik-Transportasi-Darat-2015."

[6] Pemerintah Republik Indonesia, "Undangundang Republik Indonesia nomor 22 tahun 2009 tentang lalu lintas dan angkutan jalan,” vol. 203. Jakarta, 2009.

[7] “Jumlah Kecelakaan Mudik Turun, Pelanggaran Lalu Lintas Naik,” 2016. [Online]. Available: http://nasional.kompas.com/read/2015/07/21/18 553171/Jumlah.Kecelakaan.Mudik.Turun.Pelan ggaran.Lalu.Lintas.Naik.
[8] Atika Novy Primulyati, "Fenomena Pengendara Motor di bawah Umur di jalan Kesatriaan Kidul kota Magelang,” Bachelor Proposal, vol. 1. 2015.

[9] A. T. Madyanti, "Hubungan Antara Intensitas Bermain Game Balapan Online dengan Aggressive Driving pada Remaja,” Universitas Muhammadiyah Surakarta, 2011.

[10] T. Mazuryk and M. Gervautz, "Virtual realityhistory, applications, technology and future," J. Comput. Technol., 1996.

[11] E. Setiawan, "Kamus Besar Bahasa Indonesia (KBBI) Online,” KBBI Indones., 2012.

[12] J. Dewey, Experience and education. New York: Kappa Delta Pi, 2007.

[13] T. Rostitawati, "Konsep pendidikan john dewey,” J. Manaj. Pendidik. Islam, vol. 2, pp. 133-139, 2014.

[14] D. Arsenault, "Video game genre, evolution and innovation,” Eludamos. J. Comput. Game Cult., vol. 3, no. 2, pp. 149-176, 2009.

[15] J. Steven E, The Meaning of Video Games gaming and textual strategies. New York: Routledge, 2008.

[16] B. Lange et al., "Designing informed gamebased rehabilitation tasks leveraging advances in virtual reality,” Disabil. Rehabil., vol. 34, no. 22, pp. 1863-1870, 2012. 